\title{
Penerapan Kampanye Sosial dalam Desain Komunikasi Visual
}

\author{
Risvi Pangestu ${ }^{1)}$ \\ ${ }^{1)}$ Program Studi Desain Komunikasi Visual, Pascasarjana Institut Seni Indonesia Yogyakarta \\ Jl Suyodiningratan No.8, Suryodiningratan, Kec. Mantrijeron, Kota Yogjakarta, DI Yogyakarta 55143 \\ Email : risvipangestu@gmail.com ${ }^{1)}$
}

\begin{abstract}
Communication is the key to a comprehensive effort to form a positive goal. Planned communication creates certain effects on a large number of audiences that are carried out sustainably over a period of time. Campaigns often use the media as a message sending channel that has been well organized to target targets as planned. The campaign which currently has a high existence is a campaign oriented social mission as a series of planned non-commercial communication processes that contain messages about social problems that occur in the community. In the design process, there are data collection methods and data analysis methods before executing execution. The data collected is in the form of facts, daily targets, and casual diction so that the data can be a creative media that fits the characteristics of the target audience. The author takes the topic The Role of Social Campaign Media With Visual Communication Design due to the author's interest in delivering messages that are made creative and interactive by a visual communication design to be able to make other individuals change their minds. Analysis of this work contains observations related to design elements, campaign media and campaign communication processes designed. The 16 Days Campaign Against Violence Against Communities relies on print ads and interactive ambient ads as an effort to raise awareness of target targets to combat related cases.
\end{abstract}

Keywords : Communication, Design, Campaign, Woman

\begin{abstract}
ABSTRAK
Komunikasi menjadi kunci dari sebuah usaha komperhensif dalam membentuk suatu tujuan yang positif. Komunikasi secara terencana menciptakan efek tertentu pada sejumlah besar khalayak yang dilakukan secara berkelanjutan pada kurun waktu tertentu. Kampanye kerap menggunakan media sebagai saluran pengirim pesan yang telah ditata dengan baik kepada target sasaran sesuai yang telah direncanakan. Kampanye yang saat ini memiliki eksistensi yang tinggi adalah kampanye misi sosial yang berorientasi sebagai serangkaian proses komunikasi terencana bersifat nonkomersil yang berisi pesan tentang masalah sosial yang terjadi di masyarakat. Dalam proses perancangan, terdapat metode pengumpulan data dan metode analisis data sebelum melakukan pengerjaan eksekusi. Data yang dikumpulkan berupa fakta kasus, keseharian target sasaran, serta diksi yang kasual sehingga data tersebut dapat menjadi media kreatif yang sesuai dengan karakteristik target sasaran. Adapun penulis mengambil topik Peranan Media Kampanye Sosial Dengan Desain Komunikasi Visual dikarenakan ketertarikan penulis terhadap penyampaian pesan yang dibuat kreatif dan interaktif oleh seorang desain komunikasi visual hingga mampu membuat individu yang lain berubah pikiran. Analisis karya ini berisikan pengamatan terkait elemen desain, media kampanye dan proses komunikasi kampanye yang dirancang. Kampanye 16 Hari Anti Kekerasan Terhadap Masyarakat mengandalkan print ads dan ambient ads yang interaktif sebagai upaya mengugah kesadaran target sasaran untuk memerangi kasus terkait.
\end{abstract}

Kata kunci : Komunikasi, Desain, Kampanye, Perempuan 


\section{Pendahuluan}

Dewasa ini, Desain komunikasi visual merupakan suatu bentuk komunikasi dalam bentuk visual berupa gambar untuk menyampaikan informasi atau pesan dengan efekif. Dalam desain komunikasi visual, teks juga dianggap gambar karena merupakan hasil abstraksi dari simbol-simbol yang bisa dibunyikan. Seperti jenis desain lainnya, desain komunikasi visual dapat merujuk kepada proses pembuatan, metode merancang, produk yang dihasilkan rancangan, atau pun disiplin ilmu yang digunakan desain.

Menurut ahli Hafied Cangara (2000) dalam Pengantar Ilmu Komunikasi mencatat bahwa komunikasi bisa berlaku sebagai seni. Berkaitan dengan komunikasi, Roger dan Storey (1987) menjelaskan kampanye sebagai rangkaian tindakan komunikasi yang terencana dengan tujuan untuk menciptakan efek tertentu pada sejumlah besar khalayak yang dilakukan secara berkelanjutan pada kurun waktu tertentu. Keterkaitan komunikasi dengan kampanye tentu tidak terlepas dari usaha penyebaran pesan-pesan memperbincangkan tentang dimensi perubahan pada individu dan masyarakat.

Pada umumnya semua bentuk kampanye selalu menggunakan media sebagai saluran pengirim pesan yang telah ditata dengan baik kepada target sasaran yang telah direncanakan sebelumnya. Charles U. Larson (1992) sendiri membagi jenis kampanye ke dalam tiga kategori, yakni kampanye produk, kampanye pencalonan kandidat, dan kampanye misi sosial. Adapun pada Kampanye produk (Product oriented campaigns) merupakan kegiatan kampanye yang berorientasi komersial, seperti peluncuran produk baru. Kampanye ini biasanya sekaligus bermuatan kepentingan untuk membangun citra positif terhadap produk barang yang diperkenalkan ke publik. Pada Kampanye pencalonan kandidat (Candidate Oriented Campaigns) adalah kampanye yang berorientasi politik, seperti kampanye Pemilu dan Pilkada. Sedangkan Kampanye ideologi atau misi sosial (Ideological or Cause Oriented Campaigns) adalah kampanye yang bersifat khusus keagamaan, berdimensi sosial, atau perubahan sosial. Ketiga kampanye ini dapat berkaitan dengan desain komunikasi visual. Penyampaian pesan yang umumnya menyangkut hal yang kompleks mampu diminimalisir dengan adanya peran dari desain komunikasi visual yang diaplikasikan ke media. Elemen-elemen yang ada pada desain komunikasi visual bertujuan untuk lebih memudahkan target sasaran kampanye untuk menyadari isi dari kampanye yang dibuat.

Proses membangkitkan masyarakat yang efektif harus berdasarkan kepada kebutuhan dan kepentingan bersama

antara semua pelaku yang terlibat. Usaha komprehensif yang meliputi banyak komponen, seperti pesan, pencapaian akar rumput, media massa, pemerintah, dan dana untuk mendukung pencapaian tujuan khusus merupakan isu kunci dan menyebabkan perancangan kampanye yang mampu perubahan perilaku menjadi lebih positif.
Kampanye yang saat ini memiliki eksistensi yang tinggi adalah kampanye misi sosial yang berorientasi sebagai serangkaian proses komunikasi terencana bersifat non-komersil dalam kurun waktu teretentu yang berisi pesan tentang masalah sosial yang terjadi di masyarakat. Hasil yang kampanye ini akan melibatkan masyarakat dalam proses mengubah perilaku individu hingga merubah norma-norma sosial. Tahapan sebuah perencanaan kampanye itu sendiri meliputi penetapan tujuan, target sasaran dan pesan yang efektif, baik dalam periode jangka panjang maupun dalam berbentuk skala individu.

Fenomena dari kampanye dianalisis dengan image visual, bermula dari desain komunikasi visual yang mentransmisikan pesan kepada penerima pesan melalui tanda visual yang dikirimkan. Tanda-tanda visual berupa tulisan dan gambar merupakan objek dengan kajian desain komunikasi visual yang mengaitkan unsur semiotika didalamnya. Bentuk dari visual kampanye secara efektif menyampaikan pesan dengan strategi kreatif. Sehingga, konsep yang ada pada kampanye mampu dianalisis dengan metode-metode perancangan desain komunikasi visual. Dalam proses perancangan, terdapat metode pengumpulan data dan metode analisis data sebelum melakukan pengerjaan eksekusi. Data yang dikumpulkan berupa fakta kasus, keseharian target sasaran, serta diksi yang kasual sehingga data tersebut dapat menjadi media kreatif yang sesuai dengan karakteristik target sasaran.

Berdasarkan penjelasan singkat diatas, penulis menguraikan peran media kampanye sosial dengan desain komunikasi visual. Fokus dari pembahasan ini adalah uraian pesan kampanye yang divisualisasikan dalam disiplin ilmu desain komunikasi visual. Adapun penulis mengambil topik Peranan Media Kampanye Sosial Dengan Desain Komunikasi Visual dikarenakan ketertarikan penulis terhadap penyampaian pesan yang dibuat kreatif dan interaktif oleh seorang desain komunikasi visual hingga mampu membuat individu yang lain berubah pikiran.

\section{A. Tujuan}

Tujuan dari penelitian ini adalah untuk mengetahui seberapa pentingnya peranan kampanye dan medianya serta sebagai acuan dalam merancang sebuah kampanye yang berbasis Desain Komunikasi Visual.

\section{B. Tinjauan Karya}

Pada kajian dalam Peranan Media Kampanye Dalam Desain Komunikasi Visual, penulis menganalisis karya dari seorang desainer Indonesia bernama Evelyn Gasman. Karya dari Evelyn ini berjudul "Kampanye Sosial 16 Hari Anti Kekerasan Terhadap Perempuan" dengan nama gerakan kampanye sosial 1 Sentuhan 6 Gerakan yang di aplikasikan di mall Kelapa Gading, Central Park, dan Plaza Senayan pada tahun 2015. Analisis karya ini berisikan pengamatan terkait elemen desain, media kampanye dan proses komunikasi kampanye yang dirancang. Kampanye 16 Hari Anti Kekerasan Terhadap Masyarakat mengandalkan print ads dan ambient ads yang interaktif sebagai upaya 
mengugah kesadaran target sasaran untuk memerangi kasus terkait.

\section{Landasan Teori}

1. Teori Kampanye Sosial

Kampanye pada prinsipnya merupakan suatu proses kegiatan komunikasi individu atau kelompok yang dilakukan secara terlembaga dan bertujuan untuk menciptakan suatu efek atau dampak tertentu. Rogers dan Storey 1987 mendefinisikan kampanye sebagai serangkaian tindakan komunikasi yang terencana dengan tujuan untuk menciptakan efek tertentu pada sejumlah besar khalayak yang dilakukan secara berkelanjutan pada kurun waktu tertentu (Venus, 2004:7). Kampanye merupakan wujud tindakan komunikasi yang mencakup keseluruhan proses dan fenomena praktik kampanye yang terjadi dilapangan.

Setiap aktivitas kampanye komunikasi mengandung empat hal, yaitu tindakan kampanye yang ditujukan untuk menciptakan efek atau dampak tertentu, jumlah khalayak sasaran yang besar, dipusatkan dalam kurun waktu tertentu, dan melalui serangkaian tindakan komunikasi yang terorganisir. Kampanye juga memiliki ciri atau karakteristik yaitu sumber yang jelas, yang menjadi penggagas, perancang, penyampai sekaligus penanggung jawab suatu produk kampanye (campaign makers), sehingga setiap individu yang menerima pesan kampanye dapat mengidentifikasi bahkan mengevaluasi kredibilitas sumber pesan tersebut setiap saat. Pesanpesan kampanye terbuka untuk didiskusikan, bahkan gagasan-gagasan pokok yang melatarbelakangi diselengarakannya kampanye terbuka untuk dikritisi. Keterbukaan seperti ini karena gagasan dan tujuan kampanye pada dasarnya mengandung kebaikan.

Ramlan secara spesifik mendefinisikan kampanye sosial sebagai sebuah proses untuk mengomunikasikan pesan-pesan yang berisi tentang masalah-masalah sosial kemasyarakatan dan juga bersifat non-komersil. Tujuan umum dari kampanye sosial sendiri adalah untuk menumbuhkan kesadaran masyarakat akan gejala sosial yang sedang terjadi (Ramlan, 2006:19). Kampanye sosial dikatakan sebuah proses dan serangkaian tindakan komunikasi terencana maka diperlukan strategi yang tepat untuk dapat menyampaikan pesan secara efektif terhadap target sasaran. Berdasarkan penjelasanpenjelasan dapat disimpulkan bahwa kampanye sosial adalah serangkaian proses komunikasi terencana bersifat nonkomersil dalam kurun waktu tertentu yang berisi pesan tentang masalah sosial yang terjadi di masyarakat.

2. Teori Desain Komunikasi Visual

Terapan teori Desain Komunikasi Visual dalam hal kampanye berfokus pada navigasi yang lebih playful namun edukatif dan informatif. Armin Vit mengatakan dalam prinsip Information Design, bahwa desainer mengorganisir dan menata informasi harus menjadi lebih mudah di mengerti juga inovatif, berkiasan, efisien, dan memikat masyarakat".

Desainer grafis mengidentifikasikan target sasaran, dan menganalisa hal yang dapat menjadi fokus dalam desain komunikasi visual. Analisa ini tidak terlepas dari elemen dari Desain Komunikasi Visual berupa warna, format, tekstur, ruang, garis, dan bentuk, serta prinsip Desain Komunikasi Visual seperti kesatuan, keseimbangan, proporsi, irama, dan dominasi. Dalam kaitannya dengan tujuan meningkatkan kunjungan target sasaran, maka yang menjadi fokus adalah hal-hal yang menarik minat mereka untuk ikut serta dalam kampanye ini. Dengan semua analisa yang telah di klarifikasi, maka dapat diinformasikan kepada target sasaran melalui media media promosi yang tepat dan menarik. Diharapkan dengan promosi yang menarik, dapat menarik minat target sasaran dan berhasil menaikan jumlah target sasaran.

\section{Teori Tipografi}

Dalam buku Tipografi dalam Desain komunikasi visual oleh Danton Sihombing, menjelaskan sintaksis dalam tipografi memiliki pengertian sebagai sebuah proses penataan elemen-elemen visual ke dalam kesatuan bentuk yang kohesif, studi terhadap sintaksis tipografi dimulai dari elemen komposisi yang terkecil yaitu huruf, kata garis, kolom, dan margin.

4. Teori Ilustrasi

Menurut Jim Aitchoison, ilustrasi yang baik harus dapat menguraikan masalah dan mampu bercerita serta mendeskripsikan ide yang diwakilkannya, sehingga pembaca dapat memperoleh informasi.

5. Teori Komunikasi Massa

Teori ini dikembangkan oleh Sandra BallRokeachdan Melvin L. DeFluer (1976), yang memfokuskan pada kondisi struktural suatu masyarakat yang mengatur kecenderungan terjadinya suatu efek media massa. Teori ini berangkat dari sifat masyarakat modern, dimana media massa diangap sebagai sistem informasi yang memiliki peran penting dalam proses memelihara, perubahan, dan konflik pada tataran masyarakat,kelompok, dan individu dalam aktivitas sosial. Secara ringkas kajian terhadap efek tersebut dapat dirumuskan dapat dirumuskan sebagai berikut: (1) Kognitif, menciptakan atau menghilangkan ambiguitas, pembentukan sikap, agenda-setting, perluasan sistem keyakinan masyarakat, penegasan/ penjelasan nilai-nilai. (2) Afektif, menciptakan ketakutan atau kecemasan, dan meningkatkan atau menurunkan dukungan moral. (3) Behavioral, mengaktifkan atau menggerakkan atau meredakan, pembentukan isu tertentu atau penyelesaiannya, menjangkau atau menyediakan strategi untuk suatu aktivitas serta menyebabkan perilaku dermawan.

\section{Teori Media}

Menurut Cangara (2006:119), media adalah "alat atau sarana yang digunakan untuk menyampaikan pesan dari komunikator kepada khalayak". Beberapa pakar psikologi memandang bahwa dalam komunikasi antar manusia, media yang paling dominasi dalam berkomunikasi adalah indera manusia seperti mata dan telinga. Pesan-pesan yang diterima selanjutnya oleh indera selanjutnya diproses oleh pikiran manusia untuk mengontrol dan menentukan sikapnya terhadap sesuatu sebelum dinyatakan dalam tindakan. Jadi dapat disimpulkan bahwa media merupakan sarana penyampai 
pesan dari komunikator melalui indera kepada khalayak untuk diproses sebagai sebuah informasi untuk dipahami oleh penerimanya. Sebuah kampanye memerlukan sarana implementasi yaitu lewat penggunaan media. Tujuan media yang menentukan kebutuhan atas jangkuan (reach), frekuensi (frequency), dan keseimbangan (continuity) atas kampanye yang akan dilakukan. Pentingnya pemilihan media dalam menyampaikan pesan menjadi salah satu elemen dalam dunia Desain Komunikasi Visual. Semakin Dekat sebuah media dengan target sasaran, menjadikan sebuah perancangan itu lebih dikenal oleh target sasaran. Tentunya, tidak hanya media, ilustrasi dan komunikasi dari isi pesan adalah 3 element yang harus ada dalam sebuah perancangan Desain Komunikasi Visual.

\section{Pembahasan}

Adanya teori kampanye sosial dalam kampanye 16 Hari Anti Kekerasan Terhadap Perempuan merupakan kerangka awal dalam tindakan untuk mempengaruhi khalayak sasaran yang telah diterapkan. Prinsip persuasi yang menjadi landasan untuk mengajak dan mendorong masyarakat untuk menerima sesuatu yang dianjurkan atas dasar kesukarelaan. Prinsip persuasi ini berpengaruh terhadap pesan dan media pada kampanye sosial 1 Sentuhan 6 Gerakan. Adanya pendekatan komunikasi mampu membuat khalayak sasaran lebih menyadari pesan yang akan di hadirkan. Terlihat pada media yang dipilih berdasarkan waktu yang ditentukan. Adanya pre media, main media, dan follow up media membuat struktur kampanye lebih tertata.

Ketiga tahapan ini memiliki proses yang berbeda hingga menjadikan proses komunikasi kepada target sasaran menjadi lebih mudah. Adapun media yang digunakan pada pre media adalah tissue, lalu pada main media terdapat iklan toilet, poster cermin, sticker dinding, iklan lift, dan majalah. Sedangkan pada follow up media terdapat katalog, brosur, $t$-shirt, dan notebook.

\section{A. Pre Media}

Pada pre media menjelaskan media yang akan diberikan kepada target sasaran sebagai umpan daya tarik awal yang akan menimbulkan rasa penasaran dari kelanjutan informasi media bersangkutan. Pada bagian ini pre media terdapat tissue dengan proses print ads. Adapun tissue ini dibagikan kepada orang yang memesan minuman di cafe-cafe. Pembagian masa pre media ini adalah dua minggu sebelum puncak kampanye dilaksanakan. Pre media merupakan media yang dibuat untuk menggugah perhatian dari khalayak sasaran. Pada media kampanye ini mereka menyiapkan tissue yang akan dibagikan kepada orang-orang yang memesan minuman di cafe. Dengan jangka waktu 2 minggu sebelum kampanye puncak berlangsung. Tujuan penggunaan media tissue sebagai media untuk memunculkan interest adalah karena tissue lebih banyak digunakan oleh perempuan. Tujuan lainnya adalah untuk menunjukkan bahwa perempuan yang menjadi korban kekerasan tidak bisa mengungkapkan penderitaannya, sehingga mereka terpaksa meminta tolong secara diamdiam dengan menuliskan permintaan tolong di atas tissue tersebut.



\section{B. Main Media}

Pada main media ditampilkan ketika masa puncak kampanye dimulai. Kampanye dimulai dengan mendirikan booth sebagai penjelasan lebih detail. Main media menjelaskan media kelanjutan yang ditampilkan kepada target sasaran sebagai media utama untuk menyadarkan target sasaran secara signifikan. Medium yang digunakan pada kampanye sosial 1 Sentuhan 6 Gerakan ini berupa iklan toilet, poster cermin, sticker dinding dan majalah dengan gabungan antaran proses print ads dan ambient ads. Adapun masa medium di main media termasuk booth informasi disajikan setelah pre media dengan kurun waktu satu minggu.

Main media merupakan media yang dibuat untuk memberikan pesan secara langsung. Media ini dapat berupa media interaktif yang dapat disebut ambient media. Penyebaran main media berkisar satu minggu. Adapun medium yang digunakan pada main media berupa iklan toilet, poster cermin, sticker dinding dan majalah Penggunaan toilet sebagai aplikasi dari main media dikarenakan kapasitas ruang yang tidak terlalu besar sehingga mampu menarik perhatian. Pengunjung mall akan masuk ke toilet untuk keperluan mereka. Benda yang terdapat di toilet sering kali menjadi objek yang digunakan oleh pengunjung mall, pengaplikasian main media di objek tersebut akan mampu mengugah target sasaran.

\section{Poster Cermin}

Pada poster cermin tujuan komunikasi dengan menempelkan poster di cermin adalah untuk mengajak para perempuan untuk bercermin, apakah mereka merupakan korban kekerasan atau bukan. Jika mereka adalah korban kekerasan, mereka dapat melapor kepada situs yang tertera. Tapi jika mereka bukan korban kekerasan, mereka dapat turut berpartisipasi dengan menjadi relawan untuk kampanye sosial 1 Sentuhan 6 Gerakan. Poster ini berguna untuk menimbulkan minat masyarakat sehingga muncul rasa penasaran. 




Gambar 2. Poster Cermin

\section{Sticker Dinding}

Setelah adanya poster cermin terdapat sticker dinding yang berisikan informasi singkat tentang kekerasan terhadap perempuan akan ditempel di beberapa tempat dan di dalam bilik toilet. Dalam tahap ini terdapat pendalaman dan penambahan pengetahuan masyarakat sehingga diharapkan terjadi kesadaran di dalam diri masyarakat.

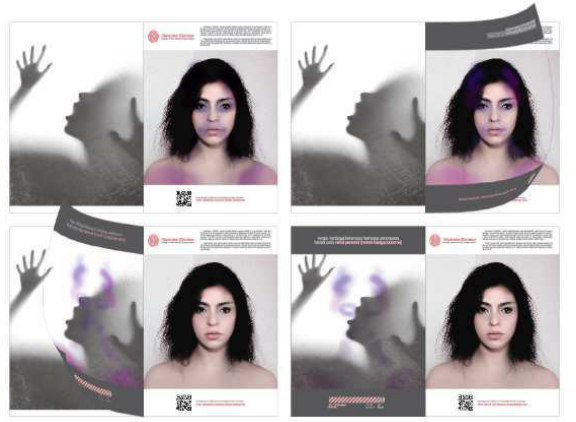

Gambar 3. Sticker Dinding

\section{Sticker Lantai}

Pada lantai diberi sticker lantai dengan tujuan menarik target sasaran menjadi lebih peka terhadap kasus kekerasan yang terjadi. Dengan pola berjalan tanpa menginjak tubuh perempuan pada sticker yang tertempel membuat target sasaran saling menghargai.

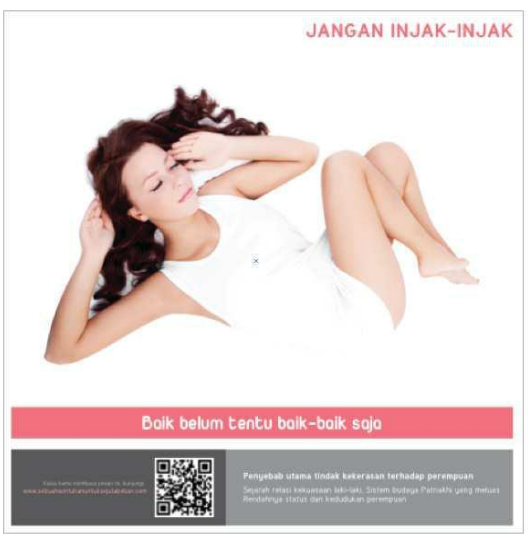

Gambar 4. Sticker Lantai
4. Majalah

Setelah pengaplikasian di toilet, kampanye ini juga membuat iklan majalah yang diletakkan di booth sebagai informasi dan bacaan interaktif untuk target sasaran. Halaman utama ditutupi dengan halaman transparan yang terdapat memar-memar, namun ketika halaman transparan itu dibalik terdapat informasi tentang apa itu kampanye sosial 1 Sentuhan 6 Gerakan.

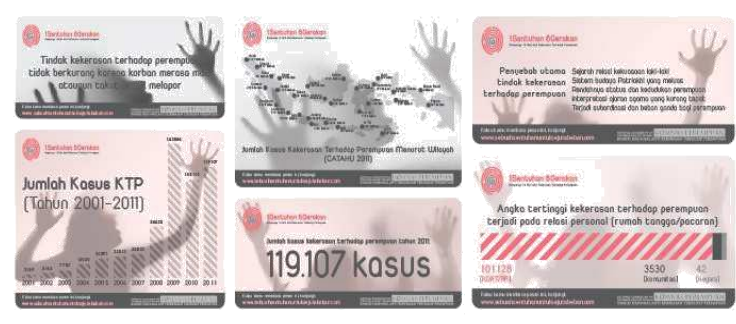

Gambar 5. Majalah

\section{Follow up Media}

Follow up media adalah media pendukung sekaligus menjadi media pengingat dari adanya kampanye sosial 1 Sentuhan 6 Gerakan. Follow up media berisikan katalog, brosur, dan notebook yang akan dibawa pulang oleh target sasaran. Target sasaran yang mendatangi booth kampanye akan mendapatkan media pendukung yang akan dibawa pulang. Media yang telah mereka bawa pulang akan menjadi media pengingat mereka untuk sadar akan bahaya dari kekerasan terhadap perempuan dan peduli terhadap kasus kekerasan terhadap perempuan.

Follow up media adalah media pendukung sekaligus menjadi media pengingat dari adanya kampanye sosial 1 Sentuhan 6 Gerakan. Follow up media berisikan katalog, brosur, dan notebook yang akan dibawa pulang oleh target sasaran. Media pendukung ini memiliki jangka waktu yang paling panjang diantara semua media, karena media yang telah dibagikan telah sampai di target sasaran.

1. Katalog

Pada katalog berisikan 6 halaman yang akan dipenuhi informasi kampanye sosial 1 Sentuhan 6 Gerakan. Penyebaran katalog ini difungsikan sebagai informasi penyadaran sehingga target sasaran ingin ikut bertindak terhadap kasus kekerasan.

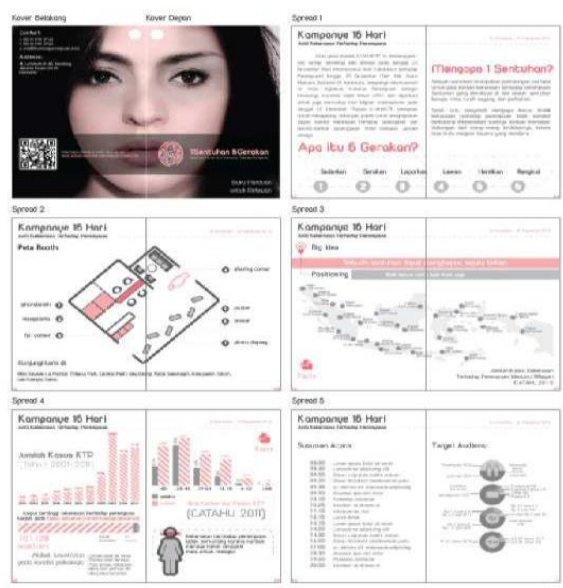

Gambar 6. Katalog 


\section{Brosur}

Brosur disebarkan seperti katalog yaitu pada saat kampanye puncak berlangsung. Brosur berisikan informasi yang dijabarkan tentang kekerasan terhadap perempuan.

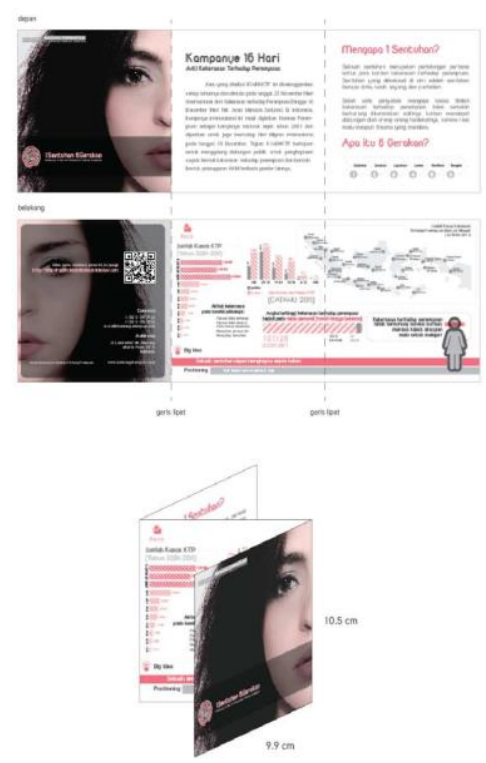

Gambar 7. Brosur

\section{Notebook}

Notebook atau yang difungsikan sebagai buku catatan dibuat sebagai marchandise untuk relawan kampanye sosial 1 Sentuhan 6 Gerakan sebagai awal dari apresiasi mereka untuk peduli.


Gambar 8. Notebook

Pada kampanye sosial 1 Sentuhan 6 Gerakan membuat sebuah logo yang dijadikan identitas dari kampanye ini. Pada logo kampanye sosial 1 Sentuhan 6 Gerakan menggunakan logogram dari bentuk sidik jari. Penambahan angka 16 pada tengah sidik jari menandakan kampanye ini dilangsungkan selama 16 hari. Lalu, pada warna yang terdapat di logogram menggunakan warna merah muda dan abu-abu, dengan persentasi warna sebanyak 6 macam. Pemilihan warna merah melambangkan feminim, cinta, kasih sayang, kelembutan dari seorang perempuan, sedangkan pemilihan warna abu-abu menjelasan karakter yang tenang, serius, kesederhanaan dan kesedihan.

Pada kampanye sosial 1 Sentuhan 6 Gerakan ini menggunakan typeface dengan keterbacaan yang baik, yaitu deupuntozero dan tuffy. Keduanya memiliki kesan yang berbeda dalam menyampaikan informasi. Untuk headline menggunakan typeface Duepuntozero untuk menonjolkan kesan santai, simple, dan informal supaya lebih tertuju pada target sasaran. Size disesuaikan dengan keadaan layout. Untuk penulisan subhead dan body text digunakan typeface Tuffy. Jenis huruf Tuffy merupakan jenis huruf yang sederhana, bersih, dan mudah dikenali. Huruf ini memiliki fleksibilitas dan kejelasan baca yang tinggi. Size disesuaikan dengan media.

Pada ilustrasi yang terdapat pada kampanye sosial 1 Sentuhan 6 Gerakan terdapat illustrasi berupa foto yang menunjukan wanita yang merupakan korban kekerasan terhadap perempuan tanpa memperlihatkan bagian tubuh yang seronok tetapi dengan ekspresi yang mengandung pesan. Pesan ini lebih ditonjolkan lagi dengan adanya ilustrasi lebam yang membuat pesan menjadi lebih interaktif.

Pada kampanye sosial 1 Sentuhan 6 Gerakan menjadikan komunikasi massa sebagai acuan dalam pemilihan media. Emosional dari penerima pesan berdasarkan komunikasi tagline yang digunakan dalam kampanye Anti Kekerasan Terhadap Perempuan ini yaitu "satu sentuhan untuk menghapus sejuta beban". Hal ini menjadikan kampanye sosial anti kekerasan terhadap perempuan sebagai suatu wadah yang bermaksud menyebarkan rasa empati dan kepedulian kepada korban yang mengalami diskriminasi gender dan eksploitasi dalam kehidupan sosial. Dalam hal ini tagline dari kampanye ini adalah "Baik belum tentu baik-baik saja". Hal ini dimaksudkan dalam rangka mengangkat fakta bahwa para perempuan korban kekerasan merasa malu dan trauma sehingga mereka memilih untuk menutupi penderitaan mereka.

Pada media kampanye sosial 1 Sentuhan 6 Gerakan menyajikan media yang sangat interaktif. Media interaktif ini mampu disebut sebagai ambient media. Ambient media adalah sebuah media yang mendominasi pemanfaatan medium publik untuk kegiatan komunikasi, sering juga disebut media tak terduga dan bersifat kejutan. Keunggulan pemilihan ambient media sebagai media kampanye anti kekerasan terhadap perempuan yang diterapkan di ruangan seperti toilet menjadikan kampanye anti kekerasan terhadap perempuan sebagai pusat perhatian.

\section{Kesimpulan}

Kampanye pada hakikatnya adalah tindakan komunikasi yang bersifat goal oriented. Pada kegiatan kampanye selalu ada tujuan yang hendak dicapai. Pencapaian tujuan tersebut tentu saja tidak dapat dilakukan melalui tindakan yang sekenanya, melainkan harus didasari pengorganisasian tindakan secara sistematis dan strategis. Dalam strategi komunikasi Kampanye 16 Hari Anti Kekerasan Terhadap Perempuan ini dilakukan pendekatan target sasaran dalam rangka memperkuat konsep dari pesan yang disampaikan pada masyarakat sasaran sehingga tercipta suatu bentuk komunikasi yang efektif. 
Dalam pendekatan yang informatif, komunikasi dilakukan secara logis. Dimana penyampaian informasi dijabarkan berdasarkan fakta-fakta yang ada dan akurat termasuk dari pengumpulan data tentang kekerasan terhadap perempuan dan kuesioner. Pendekatan ini dilakukan melalui tagline campaign, body text, copy write yang sifatnya ilmiah dan mudah dimengerti oleh masyarakat sasaran yang terdapat dalam suatu kombinasi visual dalam layout. Secara emosional kampanye sosial 1 Sentuhan 6 Gerakan memiliki peran dalam mendukung penyampaian pesan atau informasi. Proses komunikasi dengan pembagian jadwal media untuk memancing rasa ingin tahu yang dilakukan secara emosional melalui visualisasi antara kombinasi foto atau image serta teknik grafis, warna, dan tagline yang menggugah.

Kreatifitas yang dibuat dengan penggunaan foto yang menunjukan wanita yang merupakan korban kekerasan terhadap perempuan tanpa memperlihatkan bagian tubuh yang seronok tetapi dengan ekspresi yang mengandung pesan dan ditambah lagi dengan aksen yang diciptakan dari mix media pada beberapa media promosi. Adanya peran tagline yang menggugah serta menggunakan warna-warna cerah dan soft sebagai warna yang bersahabat yang ditujukan untuk semua orang menjadikan kampanye sosial 1 Sentuhan 6 Gerakan lebih dekat dengan target sasaran.

Pemilihan media kampanye yang menjadikan kampanye sosial 1 Sentuhan 6 Gerakan lebih interaktif dalam menyampaikan pesan.

Pentingnya pemilihan media kampanye sesuai target sasaran menjadi salah satu elemen keberhasilan dalam berkampanye sosial, dan pada kampanye sosial 1 Sentuhan 6 Gerakan berhasil mengugah masyarakat untuk sadar akan bahaya kekerasan terhadap perempuan dan berhasil mengajak target sasaran untuk ikut berpartisipasi dalam kampanye sosial 1 Gerakan 6 Sentuhan. Semakin Dekat sebuah media dengan target sasaran, menjadikan

sebuah perancangan itu lebih dikenal oleh target sasaran. Tentunya, tidak hanya media, ilustrasi dan komunikasi dari isi pesan adalah 3 element yang harus ada dalam sebuah perancangan Desain Komunikasi Visual.

\section{Daftar Pustaka}

Aitchison, Jim. 1999. Cutting Edge Of Advertising. Singapore : Prentice Hall

Antar, Venus. 2004. Manajemen Kampanye: Panduan Teoritis dan Praktis dalam Mengefektifkan Kampanye Komunikasi. Bandung: Simbiosa Rekaatam Media.

Ball-Rokeach, S.J., \& DeFleur, M.L. 1976. A dependency model or mass-media effects. Communication Research, 3.

Cangara, Hafied. 2006. Pengantar Ilmu Komunikasi. Jakarta: PT Raja Grafindo Persada.

Coffman, Julia. 2002. "Public communication Campaign Evalution”.Harvard Family Research Project, 1-24
Evelyn.(2011). Perancangan Komunikasi Visual Untuk Mendukung Kampanye Anti Kekerasan Terhadap Perempuan.Jakarta

Gomez Palacio, Vit Armin. 2009. Graphic Design, Referenced A Visual Guide To The Language, Applications and History of Graphic Design. USA : Rockport Publisher.

Larson, Charles U. 1992. Persuasion, Reception and Responsibility. California:Wardsworth Publishing Company.

Liliweri, Alo. 2011. Komunikasi Serba Ada Serba Makna. Jakarta: Kencana Prenada Media Group.

Rosady, Ruslan. 1997. Kiat dan Strategi Kampanye Public Relation. Jakarta : PT. Raja Grafindo Persada.

Sihombing, Danton. 2015. Tipografi Dalam Desain Grafis. Jakarta : Gramedia.

Subana, M. 2009. Dasar-Dasar Penelitian Ilmiah. CV. Pustaka Setia, Bandung

Zulkarnein, Nasution. Komunikasi Pembangunan : Pengenalan Teori dan Penerapanannya. 